\title{
BROMATOMETRIC ESTIMATION OF IRBESARTAN, LOSARTAN, AND BISOPROLOL IN BULK AND TABLET FORMS: STATISTICAL ANALYSIS
}

\author{
MAI A. EL-DIDAMOONY ${ }^{1,2}$, MOHAMED E. ELSADEK ${ }^{1}$, MOHAMED \\ M. BARAKA ${ }^{1}$, SAMY M. IBRAHIM ${ }^{1}$ and MAHMOUD M. SEBAIY ${ }^{1}$ \\ 1Department of Medicinal Chemistry \\ Faculty of Pharmacy \\ Zagazig University \\ 44 519, Zagazig \\ Egypt \\ e-mail: mmsebaiy@zu.edu.eg \\ sebaiym@gmail.com \\ ${ }^{2}$ Ministry of Health \\ Egypt
}

\begin{abstract}
A new spectrophotometric method is described for determination of irbesartan, losartan and bisoprolol in bulk and pharmaceutical dosage forms using insitu generated bromine as oxidizing agent and rhodamine B as chromogenic agent. Drugs are treated with known excess of bromine and residual unreacted bromine is determined by treating with fixed amount of rhodamine B then measuring absorbance at $557 \mathrm{~nm}$. The amount of bromine reacted corresponds to the amount of each drug. Effect of acidity, bromate-bromide volume and reaction time, on the absorption were studied. Calibration curves were linear over ranges of $4-14 \mu \mathrm{g} / \mathrm{mL}, 1-5 \mu \mathrm{g} / \mathrm{mL}$, and $5-25 \mu \mathrm{g} / \mathrm{mL}$ for irbesartan,
\end{abstract}

Keywords and phrases: spectrophotometric, irbesartan, losartan, bisoprolol, rhodamine B. Received April 27, 2020 
losartan, and bisoprolol, respectively. The method was satisfactory applied for the determination of drugs in both bulk and pharmaceutical forms and results were compared statistically with reference methods.

\section{Introduction}

Irbesartan (IRB), is chemically 2-butyl-3-(\{4-[2- (2H-1, 2, 3, 4-tetrazol5-yl) phenyl] phenyl\} methyl)-1, 3-diazaspiro [4,4] non-1-en-4-one [1] as seen in Figure 1. It is an angiotensin II receptor antagonist that affect rennin angiotensin system, and is used in treatment of hypertension [2]. Several methods have been developed for determination of IRB including UV spectrophorometric methods [3-6], extractive and non-extractive spectrophotometry [7, 8], spectrofluorimetry [9], novel 96-microwell spectrofluorometry [10], HPLC [11, 12], and micro-emulsion liquid chromatography [13].

Losartan (LOS), is chemically (2-butyl-4-chloro-1-\{[2'-(1H-tetrazol-5yl)biphenyl-4-yl]methyl\}-1H-imidazol-5-yl)methanol (Figure 1) [14]. It is non-peptide angiotensin II receptor antagonist used for the treatment of hypertension [15]. Several methods have been developed for determination of LOS including UV spectrophotometry [16-18], kinetic spectrophotometry [19], HPLC [20-23], HPTLC [24], and analytical study for the charge-transfer complexes of LOS [25].

Bisoprolol (BIS) is chemically $( \pm)-1-[4-[[2-(1-m e t h y l e t h o x y)$ ethoxy] methyl] phenoxy]-3-[(1-methylethyl) amino]-2-propanol (Figure 1) [26]. It's a beta blocker used in treatment of mild to moderate hypertension [27]. Several methods had been reported for determination of BIS such as spectrophotometric methods [28-30], HPLC [31, 32], HPTLC [33], and direct compression techniques [34]. 


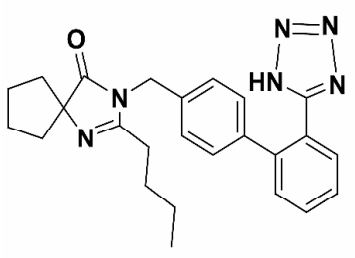

IRB

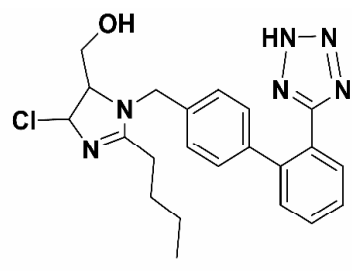

LOS

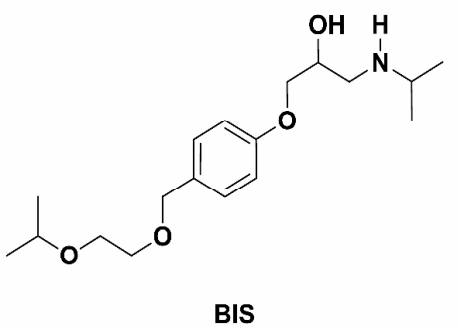

Figure 1. Chemical structures of irbesartan (IRB), losartan (LOS), and bisoprolol (BIS).

To the best of our knowledge, there is no method that has been reported for the spectrophotometric determination of the three drugs using bromatometric technique. As such, the present work introduces a simple, rapid, reproducible and sensitive method that has been established and validated for the determination of the antihypertensive drugs in their pure forms and in their tablet dosage form according to ICH guidelines [35].

\section{Materials and Method}

\subsection{Apparatus}

Labomed ${ }^{\circledR}$ Spectro UV-VIS Double Beam (UVD-2950) Spectrophotometer with matched $1 \mathrm{~cm}$ quartz cells connected to Windows compatible computer using UV Win 5Software v5.0.5 was used for experiments. 


\subsection{Materials and reagents}

All chemicals used are of analytical grade. IRB was provided by Sigma Company, Egypt, LOS was provided by Eipico Company, Egypt, while BIS was provided by Global Nabi Pharmaceuticals, 6 October City, Egypt. Standard stock solutions of IRB, LOS, and BIS equivalent to $1 \mathrm{mg} / \mathrm{mL}$ were prepared by dissolving $100 \mathrm{mg}$ of each pure drug in $100 \mathrm{~mL}$ calibrated flask with methanol. Working solutions of IRB and BIS equivalent to $100 \mu \mathrm{g} / \mathrm{mL}$ were prepared by diluting $10 \mathrm{~mL}$ from each standard stock solution with methanol in $100 \mathrm{~mL}$ calibrated flasks. On the other hand, LOS working solution equivalent to $50 \mu \mathrm{g} / \mathrm{mL}$ was prepared by diluting $5 \mathrm{~mL}$ from standard stock solution with methanol in $100 \mathrm{~mL}$ calibrated flask. Bromate-bromide stock solution was prepared by dissolving $0.10 \mathrm{gm}$ of potassium bromate and $1.00 \mathrm{gm}$ of potassium bromide in $100 \mathrm{~mL}$ distilled water. Working solution was freshly prepared daily by diluting $5 \mathrm{~mL}$ of stock solution to $100 \mathrm{~mL}$ with distilled water. $5 \mathrm{M} \mathrm{HCl}$ was prepared by diluting $225 \mathrm{~mL}$ of concentrated $\mathrm{HCl}(34 \%)$ to $500 \mathrm{~mL}$ with distilled water. Rhodamine B dye $(50 \mu \mathrm{g} / \mathrm{mL})$ was prepared by dissolving $50 \mathrm{mg}$ in $1000 \mathrm{~mL}$ distilled water (stable for 2 weeks at least).

\subsection{Pharmaceutical tablets}

The following available tablet preparations were analyzed: Kansartan ${ }^{\circledR}$ tablets, labelled to contain 150mg of IRB, batch No. 25368 (Chemipharm,

Egypt), Cozaar ${ }^{\circledR}$ tablets, labelled to contain 50mg of LOS, batch No.19460 (Merk sharp Dohme), and Concor ${ }^{\circledR}$ tablets, labelled to contain 10mg of BIS, batch No. 162697 (Amoun Pharmaceutical Company, El-Obour City, Egypt).

\subsection{General spectrophotometric procedure and construction of calibration curves}

Accurately measured aliquots of standard solutions containing $4-14 \mu \mathrm{g} / \mathrm{mL}$ of IRB, $1-5 \mu \mathrm{g} / \mathrm{mL}$ of $\mathrm{LOS}$, and $5-25 \mu \mathrm{g} / \mathrm{mL}$ of BIS were transferred into a series of $10 \mathrm{~mL}$ volumetric flasks. In case of IRB to each 
flask, $0.6 \mathrm{~mL}$ of bromate-bromide working solution was added, followed by $0.4 \mathrm{~mL}$ of $5 \mathrm{M} \mathrm{HCl}$, flasks closed and stood for 15 minutes, then $1 \mathrm{~mL}$ of rhodamine B dye was added then stood for 5 minutes. In case of LOS to each flask, $0.8 \mathrm{~mL}$ of bromate-bromide working solution was added, followed by $0.8 \mathrm{~mL}$ of $5 \mathrm{M} \mathrm{HCl}$, flasks closed and stood for 5 minutes, then $1 \mathrm{~mL}$ of rhodamine $\mathrm{B}$ dye was added then stood for 3 minutes. In case of BIS to each flask, $0.4 \mathrm{~mL}$ of bromate-bromide working solution was added, followed by $0.6 \mathrm{~mL}$ of $5 \mathrm{M} \mathrm{HCl}$, flasks closed and stood for 15 minutes, then $1 \mathrm{~mL}$ of rhodamine B dye was added then stood for 3 minutes, finally the volume was brought up to mark with distilled water for all drugs. The resulting solutions were measured at $\lambda_{\max } 557 \mathrm{~nm}$ (Figure 2) for all drugs against the blank. All these analytical parameters are mentioned in Table 1.

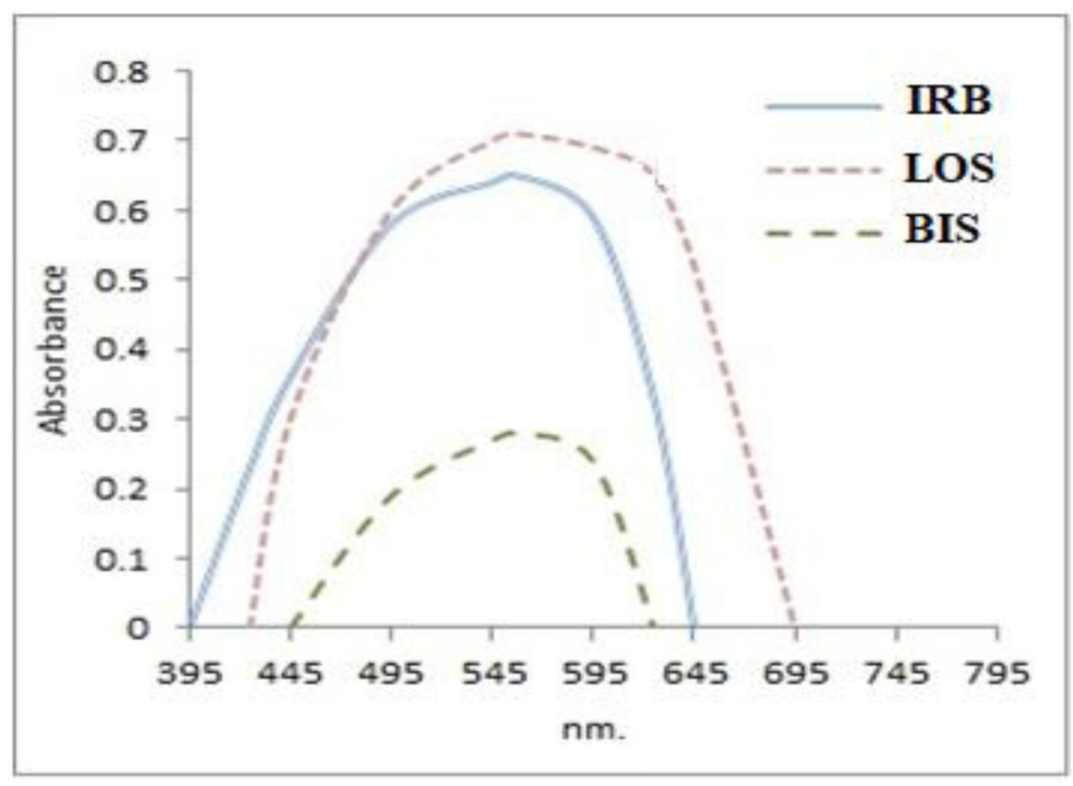

Figure 2. Absorption spectra for rhodamine $B$ in presence of IRB $(10 \mu \mathrm{g} / \mathrm{mL})$, LOS $(5 \mu \mathrm{g} / \mathrm{mL})$, and BIS $(10 \mu \mathrm{g} / \mathrm{mL})$ at $\lambda_{\max } 557 \mathrm{~nm}$. 
Table 1. Analytical parameters for the determination IRB, LOS, and BIS using rhodamine B method

\begin{tabular}{|c|c|c|c|}
\hline \multirow[t]{2}{*}{ Parameters } & \multicolumn{3}{|c|}{ Rhodamine $B(50 \mu \mathrm{g} / \mathrm{mL})$} \\
\hline & IRB & LOS & BIS \\
\hline$\lambda_{\max }, \mathrm{nm}$ & \multicolumn{3}{|c|}{557} \\
\hline Volume of $50 \mu \mathrm{g} / \mathrm{mL}$ dye, $\mathrm{mL}$ & \multicolumn{3}{|c|}{1} \\
\hline Volume of $50 \mu \mathrm{g} / \mathrm{mL}$ bromate-bromide mixture, $\mathrm{mL}$ & 0.6 & 0.8 & 0.4 \\
\hline Volume of $5 \mathrm{M} \mathrm{HCl,} \mathrm{mL}$ & 0.4 & 0.8 & 0.6 \\
\hline $\begin{array}{l}\text { Time required to oxidize the drug before dye } \\
\text { addition, min }\end{array}$ & 15 & 5 & 15 \\
\hline Time required to oxidize the dye, min & 5 & 3 & 3 \\
\hline Diluting solvent & \multicolumn{3}{|c|}{ distilled water } \\
\hline
\end{tabular}

\subsection{Procedure for pharmaceutical preparations}

Twenty tablets of Kansartan $^{\circledR}$, Cozaar ${ }^{\circledR}$, and Concor ${ }^{\circledR}$ were weighed and finely powdered. An accurately amount of the powder equivalent to the concentration of each drug in the proposed method was dissolved in $20 \mathrm{~mL}$ methanol in beaker, stirred for about 5-10 min, and filtered through Whatman ${ }^{\circledR}$ filter papers to remove the insoluble matter. The residue was washed with $10 \mathrm{~mL}$ of methanol three times, then the filtrate and washing volumes were collected and completed with methanol to $100 \mathrm{~mL}$ in volumetric flasks. Aliquots from these solutions equivalent to those in authentic samples were used for the application of the proposed method applying standard addition technique.

\section{Results and Discussion}

The proposed bromatometric method is based on the determination of the residual bromine after allowing the reaction between each drug and a measured amount of bromine to be complete. The insitu generation of bromine is carried out using a mixture of potassium bromate and 
potassium bromide in presence of $5 \mathrm{M} \mathrm{HCl}$. The surplus bromine was determined through its reaction with a fixed amount of rhodamine B dye. The method relies on the bleaching action of bromine on the dye due to oxidative destruction of rhodamine B dye [36] as seen in Figure 3. When a drug is added in increasing amounts to a fixed amount of insitu generated bromine, it consumes the latter proportionately with a concomitant fall in the concentration of bromine. When a fixed amount of dye is added to the decreasing amounts of bromine, a concomitant increase in the concentration of dye results. Consequently, a proportional increase in the absorbance at the respective $\lambda_{\max }$ is observed with increasing concentration of the drug.

$5 \mathrm{Br}-+\mathrm{BrO} 3-+6 \mathrm{H}+$

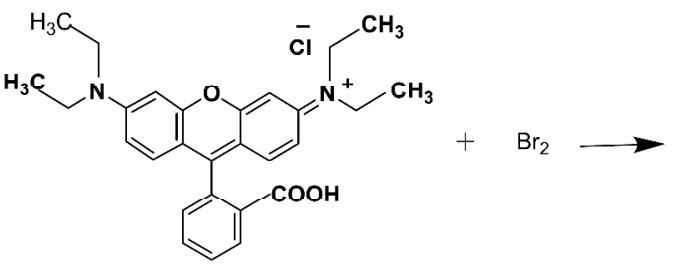

$3 \mathrm{Br} 2+3 \mathrm{H} 2 \mathrm{O}$

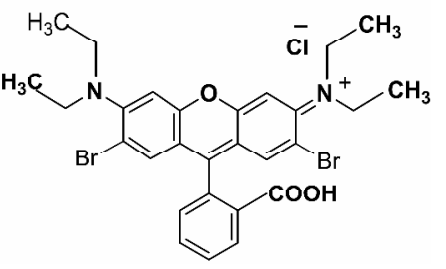

Figure 3. Proposed reaction mechanism between rhodamine $\mathrm{B}$ and $\mathrm{Br}_{2}$.

\subsection{Method optimization}

\subsubsection{Effect of bromate-bromide volume}

Bromate-bromide volume was studied by varying the reagent volume while other factors were held constant. It was found that $0.6 \mathrm{~mL}$ (in case of IRB), $0.8 \mathrm{~mL}$ (in case of LOS), and $0.4 \mathrm{~mL}$ (in case of BIS) of bromine are sufficient for its bleaching action using these stated concentrations (Figure 4). 


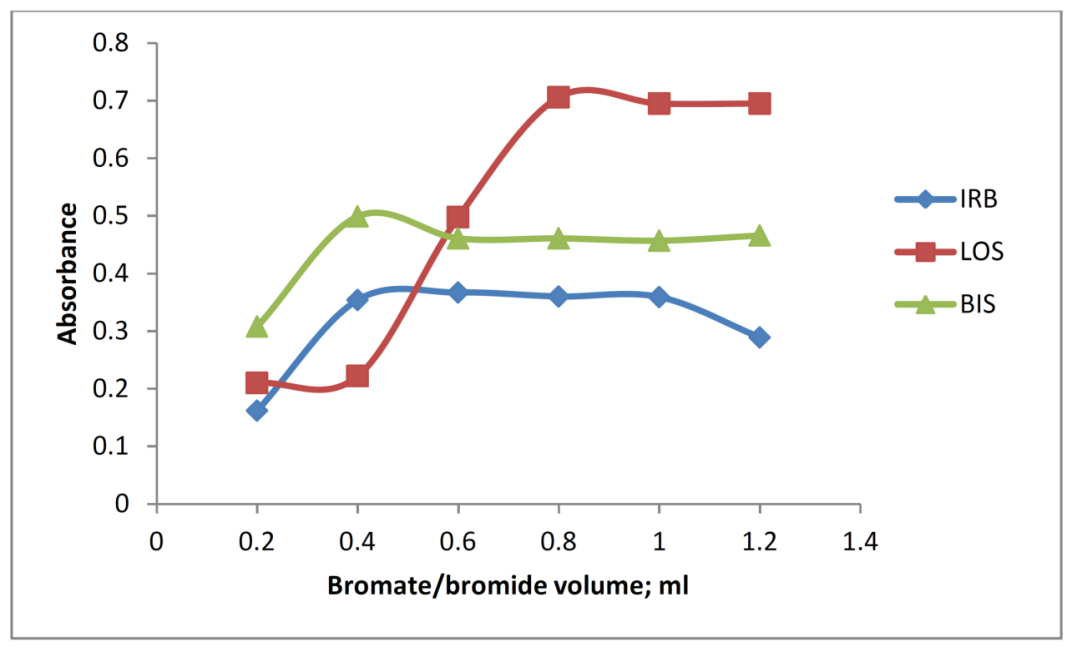

Figure 4. Effect of volume of bromate-bromide mixture on absorbance of rhodamine B in presence of IRB $(10 \mu \mathrm{g} / \mathrm{mL})$, LOS $(5 \mu \mathrm{g} / \mathrm{mL})$, and BIS $(10 \mu \mathrm{g} / \mathrm{mL})$ at $\lambda_{\max } 557 \mathrm{~nm}$.

\subsubsection{Effect of acidity}

$5 \mathrm{M} \mathrm{HCl}$ was used throughout experiments and it was found that $0.4 \mathrm{~mL}$ (in case of IRB), $0.8 \mathrm{~mL}$ (in case of LOS) or $0.6 \mathrm{~mL}$ (in case of BIS) are the appropriate acid volumes while increasing $\mathrm{HCl}$ volume results in a decrease in absorption as seen in Figure 5. 


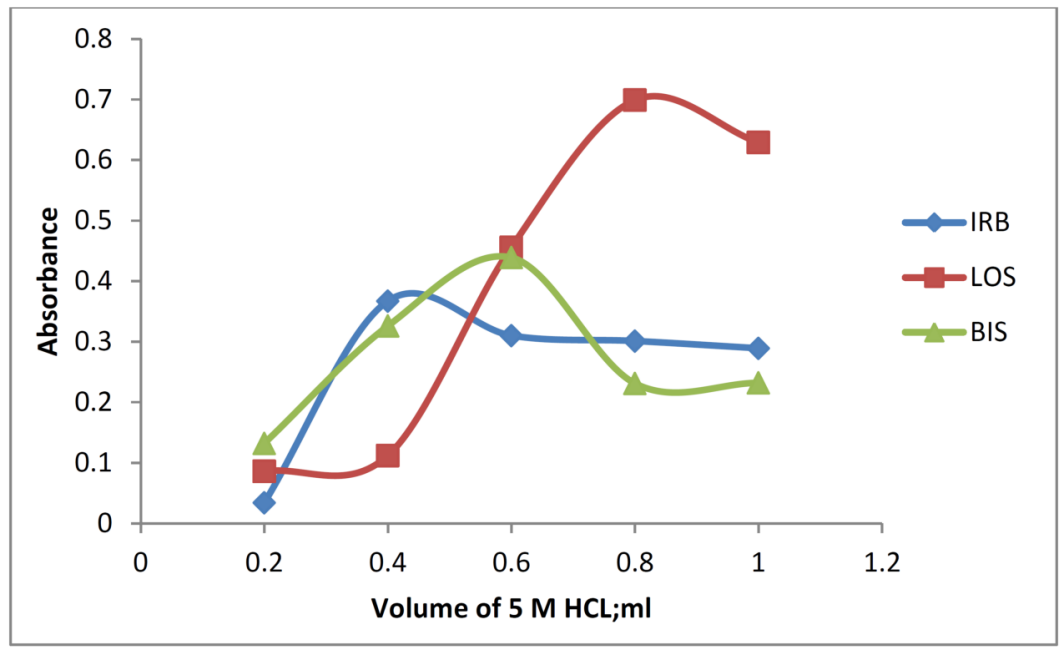

Figure 5. Effect of volume of $5 \mathrm{M} \mathrm{HCl}$ on absorbance of rhodamine $\mathrm{B}$ in presence of IRB $(10 \mu \mathrm{g} / \mathrm{mL})$, LOS $(5 \mu \mathrm{g} / \mathrm{mL})$, and BIS $(10 \mu \mathrm{g} / \mathrm{mL})$ at $\lambda_{\max } 557 \mathrm{~nm}$.

\subsubsection{Effect of time}

Time required for bromination and subsequent oxidation of the drug before addition of dye and time required to irreversibly oxidize the dye after its addition was studied. The bromination reaction was found to be complete within 15 minutes (in case of IRB and BIS) and 5 minutes (in case of LOS) as depicted in Figure 6. On the other hand, contact times of 3 minutes (in case of LOS and BIS) and 5 minutes (in case of IRB) were necessary for the bleaching of the dye colour by the residual bromine (Figure 7) and the colour of residual dye remains stable for at least two hours after mixing with the reaction mixture. 


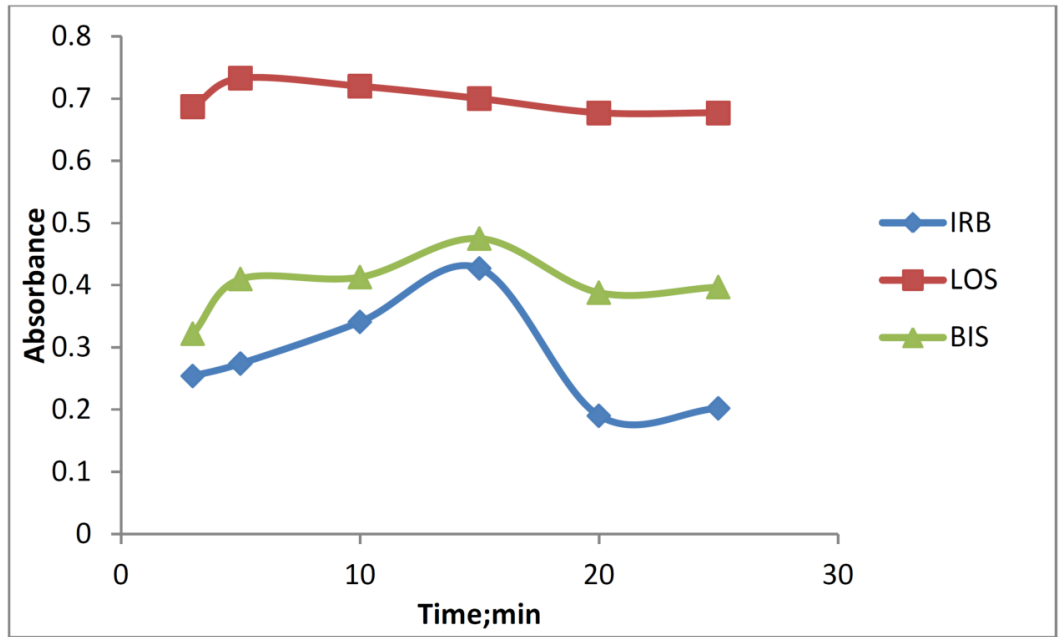

Figure 6. Effect of time before addition of rhodamine B in presence of IRB $(10 \mu \mathrm{g} / \mathrm{mL}), \operatorname{LOS}(5 \mu \mathrm{g} / \mathrm{mL})$, and BIS $(10 \mu \mathrm{g} / \mathrm{mL})$ at $\lambda_{\max } 557 \mathrm{~nm}$.

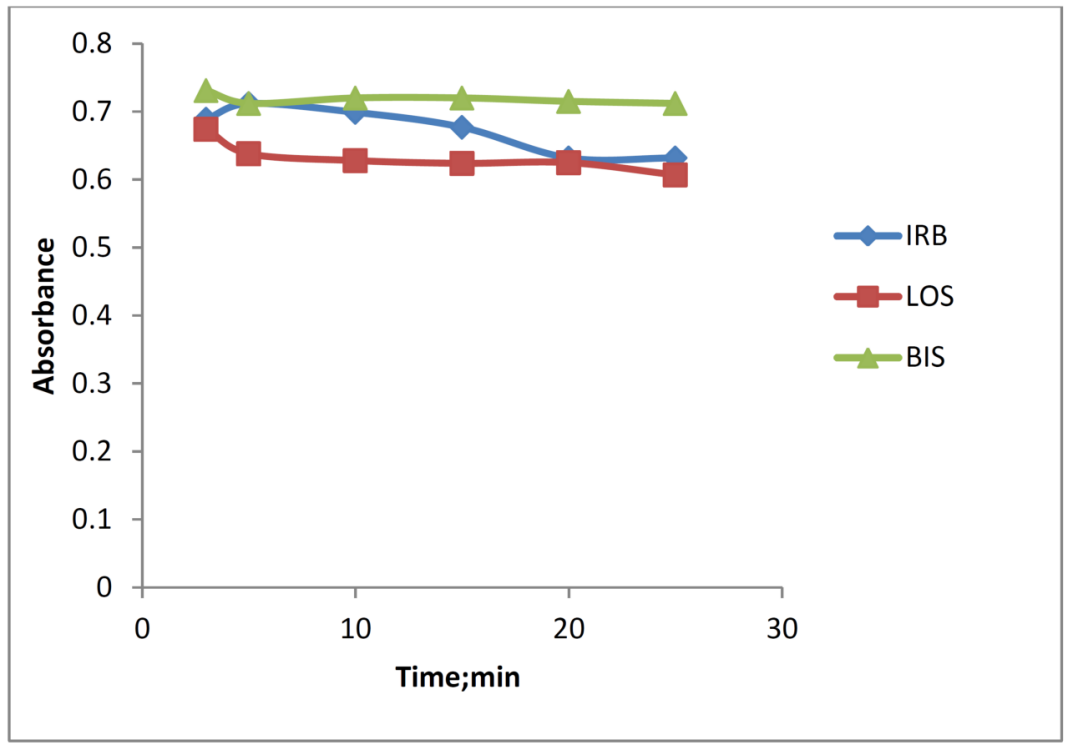

Figure 7. Effect of time after addition of rhodamine B in presence of IRB $(10 \mu \mathrm{g} / \mathrm{mL}), \operatorname{LOS}(5 \mu \mathrm{g} / \mathrm{mL})$, and BIS $(10 \mu \mathrm{g} / \mathrm{mL})$ at $\lambda_{\max } 557 \mathrm{~nm}$. 


\subsection{Method validation}

The developed method was validated according to international conference on harmonization (ICH) guidelines [35].

\subsubsection{Linearity}

Five to six different concentrations of the three drugs were prepared for linearity studies. The calibration curves obtained by plotting absorbance against concentration showed linearity in the concentration range of $4-14 \mu \mathrm{g} / \mathrm{mL}, 1-5 \mu \mathrm{g} / \mathrm{mL}$, and $5-25 \mu \mathrm{g} / \mathrm{mL}$ for IRB, LOS, and BIS, respectively. Linear regression equations of IRB, LOS, and BIS were found to be $y=0.0697 \times-0.056, y=01419 \times-0.0051, \quad$ and $\quad y=0.0172 \times+0.022$, respectively and the regression coefficient values $(r)$ were found to be 0.9999 for the three drugs indicating a high degree of linearity for all drugs as depicted in Figure 8. However, all analytical merits for the calibration data are summarized in Table 2.

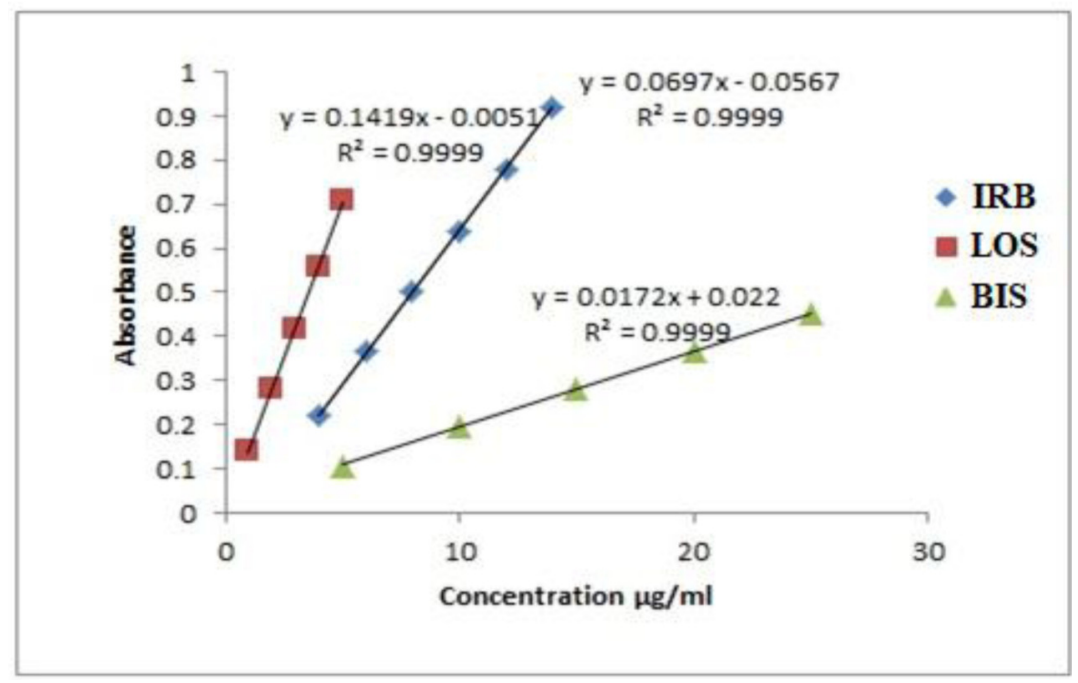

Figure 8. Calibration curves for IRB, LOS and BIS using rhodamine B method. 
Table 2. Results of the analysis for determination of IRB, LOS and BIS

\begin{tabular}{|c|c|c|c|c|c|c|}
\hline \multirow{3}{*}{ Parameters } & \multicolumn{6}{|c|}{ Rhodamine B } \\
\hline & \multicolumn{3}{|c|}{ IRB } & \multicolumn{3}{|c|}{ LOS } \\
\hline & $\begin{array}{l}\text { Taken } \\
\mu g / m L\end{array}$ & $\begin{array}{l}\text { Found } \\
\mu \mathrm{g} / \mathrm{mL}\end{array}$ & $\begin{array}{c}\text { Recovery } \\
\%\end{array}$ & $\begin{array}{l}\text { Taken } \\
\mu \mathrm{g} / \mathrm{mL}\end{array}$ & $\begin{array}{l}\text { Found } \\
\mu \mathrm{g} / \mathrm{mL}\end{array}$ & $\begin{array}{c}\text { Recovery } \\
\%\end{array}$ \\
\hline & 4 & 3.945 & 98.637 & 1 & 1.014 & 101.418 \\
\hline & 6 & 6.054 & 100.908 & 2 & 2.014 & 100.709 \\
\hline & 8 & 8.005 & 100.071 & 3 & 3.007 & 100.236 \\
\hline & 10 & 9.971 & 99.713 & 4 & 4.007 & 100.177 \\
\hline & 12 & 11.979 & 99.833 & 5 & 5.049 & 100.992 \\
\hline & 14 & 14.002 & 100.020 & & & \\
\hline Mean* & & & 99.863 & & & 100.706 \\
\hline SD & & & 0.733 & & & 0.522 \\
\hline RSD & & & 0.734 & & & 0.518 \\
\hline SE & & & 0.299 & & & 0.233 \\
\hline Variance & & & 0.537 & & & 0.272 \\
\hline Slope & & & 0.069 & & & 0.142 \\
\hline Intercept & & & 0.056 & & & 0.0051 \\
\hline $\begin{array}{l}\text { Correlation } \\
\text { Coefficient }\end{array}$ & & & 0.9999 & & & 0.9999 \\
\hline LOD & & & 1.194 & & & 0.298 \\
\hline LOQ & & & 3.983 & & & 0.997 \\
\hline $\begin{array}{c}\text { Apparent Molar* } \\
\text { bsorbitivity } \\
\mathrm{Mol}^{-1} \cdot \mathbf{c m}^{-1}\end{array}$ & & & 26642.18 & & & 59065.89 \\
\hline
\end{tabular}


Table 2. (Continued)

\begin{tabular}{|c|c|c|c|}
\hline \multirow{3}{*}{ Parameters } & \multicolumn{3}{|c|}{ Rhodamine B } \\
\hline & \multicolumn{3}{|c|}{ BIS } \\
\hline & $\begin{array}{l}\text { Taken } \\
\mu \mathrm{g} / \mathrm{mL}\end{array}$ & $\begin{array}{l}\text { Found } \\
\mu \mathrm{g} / \mathrm{mL}\end{array}$ & $\begin{array}{c}\text { Recovery } \\
\%\end{array}$ \\
\hline & 5 & 4.941 & 98.823 \\
\hline & 10 & 10.176 & 101.764 \\
\hline & 15 & 15.235 & 101.568 \\
\hline & 20 & 20.176 & 100.882 \\
\hline & 25 & 25.176 & 100.705 \\
\hline Mean* & & & 100.749 \\
\hline SD & & & 1.165 \\
\hline RSD & & & 1.156 \\
\hline SE & & & 0.521 \\
\hline Variance & & & 1.357 \\
\hline Slope & & & 0.017 \\
\hline Intercept & & & 0.022 \\
\hline $\begin{array}{c}\text { Correlation } \\
\text { Coefficient }\end{array}$ & & & 0.9999 \\
\hline LOD & & & 1.458 \\
\hline LOQ & & & 4.863 \\
\hline $\begin{array}{c}\text { Apparent Molar** } \\
\text { bsorbitivity } \\
\text { Mol }^{-1} . \mathrm{cm}^{-1}\end{array}$ & & & 6227.837 \\
\hline
\end{tabular}

*Average of three different experiments.

**Calculated in the basis of molecular weight of the drug. 


\subsubsection{Accuracy}

The accuracy of the method was determined by investigating the recovery of drugs at 5 concentration levels covering the specified range (three replicates of each concentration). Standard addition method was used for determination of IRB, LOS, and BIS in $\operatorname{Kansartan}^{\circledR}$, $\operatorname{Cozaar}^{\circledR}$, and Concor ${ }^{\circledR}$ tablets and the results showed excellent recoveries (99.873 - $100.244 \%$ ) as seen in Table 3.

Table 3. Application of standard addition technique for the determination of Kansartan ${ }^{\circledR}$, Cozaar $^{\circledR}$, and Concor $^{\circledR}$ tablets using standard addition technique

\begin{tabular}{|c|c|c|c|c|}
\hline \multirow{2}{*}{ Items } & \multicolumn{4}{|c|}{ Kansartan $^{\circledR}$ tablets (IRB) } \\
\cline { 2 - 5 } & $\begin{array}{c}\text { Added pure } \\
\text { drug }(\mu \mathbf{g} / \mathbf{m L})\end{array}$ & $\begin{array}{c}\text { Taken tablet } \\
(\mu \mathrm{g} / \mathbf{m L})\end{array}$ & $\begin{array}{c}\text { Conc. found } \\
(\mu \mathrm{g} / \mathbf{m L})\end{array}$ & $\begin{array}{c}\text { Recovery } \\
\%\end{array}$ \\
\hline & $\mathbf{6}$ & $\mathbf{0}$ & 5.941 & 99.026 \\
\hline & $\mathbf{6}$ & $\mathbf{2}$ & 7.994 & 99.937 \\
\hline & $\mathbf{6}$ & $\mathbf{4}$ & 10.065 & 100.651 \\
\hline Mean* & $\mathbf{6}$ & $\mathbf{6}$ & 12.051 & 100.431 \\
\hline SD & $\mathbf{6}$ & $\mathbf{8}$ & 13.904 & 99.320 \\
\hline RSD & & & & $\mathbf{9 9 . 8 7 3}$ \\
\hline SE & & & & 0.697 \\
\hline Variance & & & & 0.697 \\
\hline
\end{tabular}


Table 3. (Continued)

\begin{tabular}{|c|c|c|c|c|}
\hline \multirow{2}{*}{ Items } & \multicolumn{4}{|c|}{ Cozaar $^{\circledR}$ tablets (LOS) $^{*}$} \\
\cline { 2 - 5 } & $\begin{array}{c}\text { Added pure } \\
\text { drug }(\boldsymbol{\mu g} / \mathbf{m L})\end{array}$ & $\begin{array}{c}\text { Taken tablet } \\
(\mu \mathbf{g} / \mathbf{m L})\end{array}$ & $\begin{array}{c}\text { Conc. found } \\
(\mu \mathbf{g} / \mathbf{m L})\end{array}$ & $\begin{array}{c}\text { Recovery } \\
\%\end{array}$ \\
\hline & $\mathbf{2}$ & $\mathbf{0}$ & 2.000 & 100.213 \\
\hline & $\mathbf{2}$ & $\mathbf{1}$ & 3.000 & 100.284 \\
\hline & $\mathbf{2}$ & $\mathbf{2}$ & 3.962 & 99.074 \\
\hline & $\mathbf{2}$ & $\mathbf{3}$ & 5.031 & 100.626 \\
\hline Mean* & $\mathbf{2}$ & $\mathbf{4}$ & 5.992 & 99.881 \\
\hline SD & & & & $\mathbf{1 0 0 . 0 1 6}$ \\
\hline RSD & & & & 0.589 \\
\hline SE & & & & 0.589 \\
\hline Variance & & & & 0.263 \\
\hline
\end{tabular}

\begin{tabular}{|c|c|c|c|c|}
\hline \multirow{2}{*}{ Items } & \multicolumn{4}{|c|}{ Concor $^{\circledR}{ }^{\circledR}$ tablets (BIS) } \\
\cline { 2 - 5 } & $\begin{array}{c}\text { Added pure } \\
\mathbf{d r u g}(\mu \mathrm{g} / \mathrm{mL})\end{array}$ & $\begin{array}{c}\text { Taken tablet } \\
(\mu \mathrm{g} / \mathbf{m L})\end{array}$ & $\begin{array}{c}\text { Conc. found } \\
(\mu \mathrm{g} / \mathrm{mL})\end{array}$ & $\begin{array}{c}\text { Recovery } \\
\mathbf{\%}\end{array}$ \\
\hline & $\mathbf{1 0}$ & $\mathbf{0}$ & 10.089 & 100.895 \\
\hline & $\mathbf{1 0}$ & $\mathbf{5}$ & 15.014 & 100.099 \\
\hline & $\mathbf{1 0}$ & $\mathbf{1 0}$ & 19.940 & 99.701 \\
\hline Mean* & $\mathbf{1 0}$ & $\mathbf{1 5}$ & 25.014 & 100.059 \\
\hline SD & $\mathbf{1 0}$ & $\mathbf{2 0}$ & 30.139 & 100.464 \\
\hline RSD & & & & $\mathbf{1 0 0 . 2 4 4}$ \\
\hline SE & & & & 0.453 \\
\hline Variance & & & & 0.452 \\
\hline
\end{tabular}

*Average of three different experiments. 


\subsubsection{Precision}

Intra-day precision was evaluated by calculating standard deviation (SD) of five replicate determinations using the same solution containing pure drugs. Results in Table 4 show that SD values (0.181-0.738) revealed the high precision of the method. For inter-day reproducibility on a day-to-day basis, a series was run, in which the standard drug solutions were analyzed each for five days where SD values were also in the acceptable range $(0.278-0.816)$ as seen in Table 4.

Table 4. Results of the intra-day and inter-day precision for the determination of IRB, LOS, and BIS with rhodamine B

\begin{tabular}{|c|c|c|c|c|c|}
\hline \multirow{2}{*}{ Drug } & \multirow{2}{*}{$\begin{array}{c}\text { Conc. } \\
\mathbf{\mu g} / \mathbf{m L}\end{array}$} & \multicolumn{2}{|c|}{ Intra-day } & \multicolumn{2}{c|}{ Inter-day } \\
\cline { 3 - 6 } & 6 & $101.449 \pm 0.483$ & 0.476 & $101.352 \pm 0.775$ & 0.764 \\
& 6 & $100.905 \pm 0.181$ & 0.179 & $101.087 \pm 0.424$ & 0.420 \\
\hline \multirow{3}{*}{ IRB } & 8 & $100.531 \pm 0.221$ & 0.220 & $100.463 \pm 0.278$ & 0.277 \\
\hline \multirow{2}{*}{ LOS } & 10 & $100.118 \pm 0.738$ & 0.737 & $99.432 \pm 0.816$ & 0.821 \\
& 3 & $99.448 \pm 0.722$ & 0.726 & $99.527 \pm 0.647$ & 0.650 \\
& 4 & $100.472 \pm 0.369$ & 0.367 & $100.886 \pm 0.396$ & 0.392 \\
\hline \multirow{2}{*}{ BIS } & 10 & $101.176 \pm 0.588$ & 0.581 & $101.058 \pm 0.766$ & 0.758 \\
& 15 & $101.568 \pm 0.392$ & 0.386 & $101.725 \pm 0.447$ & 0.442 \\
& 20 & $100.490 \pm 0.449$ & 0.447 & $100.294 \pm 0.465$ & 0.460 \\
\hline
\end{tabular}

\subsubsection{LOD and LOQ}

The calculation of limits of detection and quantification was based on the following equations: $\mathrm{LOD}=3.3 \mathrm{~S} / \mathrm{K}$ and $\mathrm{LOQ}=10 \mathrm{~S} / \mathrm{K}$, respectively, where $\mathrm{S}$ is the standard deviation of the seven replicate values under the same conditions as for the sample analysis in the absence of analyte and $\mathrm{K}$ is the sensitivity, namely, the slope of calibration graph. The limit of detection for IRB, LOS, and BIS was reported to be $1.194 \mu \mathrm{g} / \mathrm{mL}$, $0.298 \mu \mathrm{g} / \mathrm{mL}$, and $1.458 \mu \mathrm{g} / \mathrm{mL}$ while the limit of quantification was $3.983 \mu \mathrm{g} / \mathrm{mL}, 0.997 \mu \mathrm{g} / \mathrm{mL}$, and $4.863 \mu \mathrm{g} / \mathrm{mL}$, respectively (Table 2). 


\subsubsection{Robustness}

The robustness of the method was evaluated by making small changes $( \pm 0.05)$ in one parameter keeping the other spectrophotometric conditions constant such as volume of acid, bromate-bromide mixture and dye solution where the effect of the changes was studied on the percent recovery of drugs. The changes had negligible influence on the results as revealed by small SD $(\leq 1.813)$ as shown in Table 5 .

Table 5. Results of the robustness for the determination of IRB, LOS, and BIS using rhodamine B method

\begin{tabular}{|c|c|c|c|}
\hline \multirow{2}{*}{ Parameters } & \multicolumn{3}{|c|}{ Rhodamine B } \\
\cline { 2 - 4 } & IRB & of recovery \pm SD \\
\cline { 2 - 4 } & $100.770 \pm 0.839$ & $100.792 \pm 0.607$ & $100.043 \pm 1.434$ \\
\hline HCl + 0.05 & $101.183 \pm 1.118$ & $100.508 \pm 0.572$ & $100.171 \pm 1.271$ \\
\hline HCl $-\mathbf{0 . 0 5}$ & $100.797 \pm 0.830$ & $100.593 \pm 0.505$ & $100.396 \pm 1.041$ \\
\hline $\mathbf{B r}_{\mathbf{2}}+\mathbf{0 . 0 5}$ & $101.207 \pm 1.155$ & $100.536 \pm 0.543$ & $100.171 \pm 1.271$ \\
\hline $\mathbf{B r}_{\mathbf{2}}-\mathbf{0 . 0 5}$ & $100.990 \pm 0.885$ & $100.508 \pm 0.572$ & $100.043 \pm 1.434$ \\
\hline Dye $+\mathbf{0 . 0 5}$ & $100.652 \pm 0.930$ & $101.075 \pm 1.102$ & $99.730 \pm 1.813$ \\
\hline Dye $-\mathbf{0 . 0 5}$ & &
\end{tabular}

\subsection{Analysis of pharmaceutical formulations}

The validated spectrophotometric method was applied for the determination of IRB, LOS, and BIS in their pharmaceutical preparations. Results obtained were compared to those obtained by applying reported reference methods [30, 37, 38] where Student's t-test and F-test were performed for comparison. It was found that the calculated $\mathrm{t}$ and $\mathrm{F}$ values were less than tabulated ones for the cited drugs (Table 6) which in turn indicate that there is no significant difference between proposed method and reference ones relative to precision and accuracy. 
Table 6. Statistical analysis of results obtained by the proposed method applied on IRB, LOS, and BIS compared with reference methods

\begin{tabular}{|l|c|c|c|c|}
\hline \multirow{2}{*}{ Parameters } & \multicolumn{2}{|c|}{ IRB } & \multicolumn{2}{c|}{ LOS } \\
\cline { 2 - 5 } & $\begin{array}{c}\text { Proposed } \\
\text { method }\end{array}$ & $\begin{array}{c}\text { Reference } \\
\text { method [37] }\end{array}$ & $\begin{array}{c}\text { Proposed } \\
\text { method }\end{array}$ & $\begin{array}{c}\text { Reference } \\
\text { method [38] }\end{array}$ \\
\hline N & 6 & 6 & 5 & 5 \\
\hline Mean Recovery* & 99.863 & 99.989 & 100.706 & 100.004 \\
\hline SD & 0.733 & 0.699 & 0.521 & 0.657 \\
\hline RSD & 0.734 & 0.699 & 0.518 & 0.657 \\
\hline SE & 0.299 & 0.285 & 0.233 & 0.294 \\
\hline Variance & 0.537 & 0.579 & 0.272 & 0.432 \\
\hline t-test** & $0.304 \mathbf{( 2 . 2 2 8}^{\mathbf{a}}$ & & $1.872 \mathbf{( 2 . 3 0 6}^{\mathbf{a}}$ & \\
\hline F-test*** & $1.099 \mathbf{( 4 . 2 8 3 )}^{\mathbf{b}}$ & & $1.590 \mathbf{( 5 . 0 5 )}^{\mathbf{b}}$ & \\
\hline
\end{tabular}

\begin{tabular}{|l|c|c|}
\hline \multirow{2}{*}{ Parameters } & \multicolumn{2}{|c|}{ BIS } \\
\cline { 2 - 3 } & $\begin{array}{c}\text { Proposed } \\
\text { method }\end{array}$ & $\begin{array}{c}\text { Reference } \\
\text { method [30] }\end{array}$ \\
\hline $\mathbf{N}$ & 5 & 5 \\
\hline Mean Recovery* & 100.749 & 101.216 \\
\hline SD & 1.165 & 0.735 \\
\hline RSD & 1.156 & 0.727 \\
\hline SE & 0.521 & 0.300 \\
\hline Variance & 1.357 & 0.541 \\
\hline t-test** & $0.758 \mathbf{( 2 . 3 0 6}^{\mathbf{a}}$ & \\
\hline F-test** & $2.512 \mathbf{( 5 . 0 5 )}^{\mathbf{b}}$ & \\
\hline
\end{tabular}

*Average of three experiments

**a and b theoretical Student t-values and F-ratio at $p=0.05$. 


\section{Conclusion}

The proposed indirect spectrophotometric method is simple, fast, accurate, adequately sensitive and inexpensive. It is suitable for routine quality control analysis. The present method is superior to the reference methods with respect to both sensitivity and selectivity. The method has been successfully applied for the analysis of marketed tablets.

\section{Acknowledgement}

I am very thankful to the whole staff member at Department of Medicinal Chemistry, Faculty of Pharmacy, Zagazig University for providing facility to carry out the research work.

\section{References}

[1] Kaushik R. Patel, Satish A. Patel, Vinay C. Darji and Rakshit N. Sonpal, Simultaneous spectrophotometric estimation of irbesartan and hydrochlorothiazide in tablets, International Research Journal of Pharmacy 2(3) (2011), 202-207.

[2] G. Tulja Rani, D. Gowri Shankar, M. Shireesha and B. Satyanarayana, Spectrophotometric method for determination of angiotensin II: Receptor antagonist in bulk and pharmaceutical dosage forms, International Journal of Pharmacy and Pharmaceutical Sciences 4(1) (2012), 198-202.

[3] B. Anupama, Abhinav Kurumaddali, Suri Nagarjuna Bhargav and A. Surendra, UV spectrophotometric method for irbesartan, International Journal of Research in Pharmacy and Chemistry 2(1) (2012), 20-21.

[4] Srinath Nissankararao, Anil Kumar A., Rama Devi Bhimavarapu and Krishna Prasanna V., Estimation of irbesartan in bulk and dosage forms by new simple UV spectrophotometry using hydrotropic technique, Pharmaceutica Analytica Acta 4(8) (2013), 1-3.

DOI: https://doi.org/10.4172/2153-2435.1000265

[5] K. Divya, V. Sruthi, G. Sravan Kumar, Sanayaima Huidrom, M. Akiful Haque and V. V. L. N. Prasad, Simultaneous estimation of irbesartan and hydrochlorothiazide in combined pharmaceutical dosage form by UV spectroscopy, International Journal of Innovative Pharmaceutical Sciences and Research 2(8) (2014), 1674-1680.

[6] Lakshmi Sivasubramanian and K. S. Lakshmi, H-Point standard addition method for simultaneous spectrophotometric determination of irbesartan, hydrochlorothiazide and telmisartan in tablets, International Journal of Research In Pharmacy and Chemistry 4(2) (2014), 373-380. 
[7] Vemugunta Ramakrishna and B. Anupama, Assay of irbesartan by extractive spectrophotometry, International Journal of Pharmaceutical Chemical and Biological Sciences 2(4) (2012), 529-531.

[8] Mohamed M. El-Sutohy, Salwa R. El-Shaboury, Samiha A. Hussein and Niveen A. Mohamed, Validated non-extractive spectrophotometric methods for determination of some angiotensin II receptor antagonists, Asian Journal Pharmaceutical Analysis 3(1) (2013), 03-08.

[9] M. Farouk, O. Abd EL-Aziz, A. Hemdan and M. Shehata, Simple novel spectrophotometric and spectrofluorimetric methods for determination of some antihypertensive drugs, Journal of American Science 7(1) (2011), 300-312.

[10] I. A. Darwish, T. A. Wani, N. Y. Khalil and A. H. Bakheit, Novel 96-microwell spectrophotometric assays with high throughput for determination of irbesartan in its tablets, Digest Journal of Nanomaterials and Biostructures 7(2) (2012), 415-421.

[11] Krystyna Czerwinska and Aleksander P. Mazurek, Identification and determination of selected angiotensin II receptor antagonist group drugs by HPLC method, Acta Poloniae Pharmaceutical Drug Research 68(6) (2011), 831-837.

[12] Amer M. Alanazi, Ali S. Abdelhameed, Nasr Y. Khalil, A. Azmat Khan and A. Ibrahim Darwish, HPLC method with monolithic column for simultaneous determination of irbesartan and hydrochlorothiazide in tablets, Acta Pharmacy 64 (2014), 187-198.

DOI: https://doi.org/10.2478/acph-2014-0014

[13] Mohammed E. A. Hammouda, Mohamed A. Abu El-Enin, Dina T. El-Sherbiny, Dalia R. El-Wasseef and Saadia M. El-Ashry, Simultaneous determination of irbesartan and hydrochlorothiazide in pharmaceutical preparations and spiked human plasma using microemulsion liquid chromatography, International Journal of Advances in Pharmaceutical Research 4(7) (2013), 1944-1959.

[14] Kapil Kumar Goel, Nidhi Goel, Shailendra Patil and Asmita Gajbhiye, Development of new UV spectrophotometric method for estimation of losartan potassium in bulk and tablet dosage form, International Journal of Medical Sciences 2(2) (2010), 110-111.

[15] Priyanka R. Patil, Sachin U. Rakesh, P. N. Dhabale and K. B. Burade, Simultaneous UV spectrophotometric method for estimation of losartan potssium and amlodipine besylate in tablet dosage form, Asian Journal Research Chemistry 2(2) (2009), 183-187.

[16] P. L. K. M. Rao, V. Venugopal, G, Anil Kumar, B. Rajesh, G. A. L. Prasad and D. Ravindergoud, Quantitative estimation of losartan potassium in pharmaceutical dosage forms by UV-spectrophotometry, International Journal of Research in Pharmacy and Chemistry 1(3) (2011), 295-302.

[17] Pragati Kumar Bada, Prafulla Kumar Sahu and T. Abhinov, Simple spectrophotometric methods for simultaneous determination of losartan potassium and atorvastatin calcium in combined dosage forms, Journal of Chemical and Pharmaceutical Sciences 4(3) (2011), 127-131. 
[18] Pranshu Tangri, Prem Singh, Lakshmayya, Sayantan Mukhopadhyay and Shaffi Tangri, Development and validation of UV spectrophotometric method for the estimation of losartan bulk drug and pharmaceutical formulation, International Research Journal of Pharmacy 3(5) (2012), 391-393.

[19] Nafisur Rahman, Masoom Raza Siddiqui and Syed Najmul Hejaz Azmi, Development and validation of kinetic spectrophotometric method for the determination of losartan potassium in pure and commercial tablets, Journal of the Chinese Chemical Society 53(3) (2006), 735-743.

DOI: https://doi.org/10.1002/jccs.200600097

[20] T. Sivakumar, P. Venkatesan, R. Manavalan and K. Valliappan, Development of high performance liquid chromatography method for the simultaneous determination of losartan potassium and atenolol, Indian Journal of Pharmaceutical Sciences 69(1) (2007), 154-157.

[21] Khan M. Rizwan, Shaikh Anis and A. K. Thaker, Simultaneous determination and method development for assay of losartan potassium and hydrochlorothiazide drugs in solid dosage form by RP-HPLC, Indian Journal of Pharmaceutical Science \& Research 2(1) (2012), 42-45.

[22] G. Aruna, M. Chanukya and V. Mohan Reddy, Simultaneous estimation of losartan potassium and hydrochlorothiazide drugs in solid dosage form by RP-HPLC, International Journal of Medicinal Chemistry \& Analysis 2(1) (2012), 57-61.

[23] Savita S. Yadav and Janhavi R. Rao, RP-HPLC method for simultaneous estimation of losartan, hydrochlorothiazide and amlodipine in tablet dosage form, Asian Journal of Pharmaceutical and Clinical Research 7(1) (2014), 137-140.

[24] Karunanidhi S. Lakshmi, Sivasubramanian Lakshmi, Simultaneous analysis of losartan potassium, amlodipine besylate, and hydrochlorothiazide in bulk and in tablets by high-performance thin layer chromatography with UV-absorption densitometry, Journal of Analytical Methods in Chemistry (2012); Article ID 108281.

DOI: https://doi.org/10.1155/2012/108281

[25] Ibrahim A. Darwish, Analytical study for the charge-transfer complexes of losartan potassium, Analytica Chimica Acta 549(1-2) (2005), 212-220.

DOI: https://doi.org/10.1016/j.aca.2005.06.023

[26] R. B. Kakde, V. H. Kotak, A. G. Barsagade, N. K. Chaudhary and D. L. Kale, Spectrophotometric method for simultaneous estimation of amlodipine besylate and bisoprolol fumarate in pharmaceutical preparations, Research Journal Pharmacy and Technology 1(4) (2008), 513-515.

[27] Smita T. Kumbhar, Pankaj P. Shinde, Dattatrya B. Shinde and Payal B. Solankar, Visible spectrophotometric method for estimation of bisoprolol from its bulk and tablet formulation, Asian Journal of Pharmaceutical and Clinical Research 6(4) (2013), 103-105. 
[28] Alina Diana Gudruman, Andreea Murarasu and Vasile Dorneanu, Spectrophotometric determination of bisoprolol using methyl orange as reagent, Farmacia 60(5) (2012), 634-641.

[29] Alina Diana Panainte, Nela Bibire, Gladiola Tantaru, M. Apostu, Madalina Vieriu and V. Dorneanu, Spectrophotometric method for estimation of bisoprolol fumarate in tablets, Rev. Med. Chir. Soc. Med. Nat., Iasi, 118(2) (2014), 558-563.

[30] Safwan Ashour, Raghad Al-Khalil and Banana Alfares, Hydrochlorothiazide used as diuretic with antihypertensive agents in pharmaceutical preparations: Estimation by first-order derivative and extractive spectrophotometry, Canadian Chemical Transactions 2(2) (2014), 190-200.

[31] Sevgi Tatar Ulu and Zeynep Aydoğmus, An HPLC method for the determination of bisoprolol in human plasma and its application to a pharmacokinetic study, Journal of Chromatographic Science 50(7) (2012), 615-619.

DOI: https://doi.org/10.1093/chromsci/bms056

[32] Kishore Konam, Jilla Soujanya, M. Sasikala and A. Kiran Kumar, Development and validation of RP-HPLC method for the determination of bisoprolol fumarate tablets, International Journal of Research in Pharmaceutical and Nano Sciences 2(1) (2013), 57-67.

[33] Savita S. Yadav and Janhavi R. Rao, Simultaneous HPTLC analysis of bisoprolol fumarate and hydrochlorthiazide in pharmaceutical dosage form, International Journal of Pharmacy and Pharmaceutical Sciences 5(2) (2013), 286-290.

[34] N. D. Deshmukh, R. R. Thenge and N. M. Mahajan, Formulation and evaluation of bisoprolol fumarate fast dissolving tablet by direct compression techniques, International Journal of Pharmaceutical Research and Bio-Science 1(5) (2012), 364-378.

[35] International Conference on Harmonization of Technical Requirements for Registration of Pharmaceuticals for Human Use, ICH Harmonized Tripartite Guideline, Validation of Analytical Procedures: Text and Methodology Q2(R1), Complementary Guideline on Methodology dated 06 November 1996, Incorporated in November 2005, London.

[36] Abir A. Ahmed Ali and Abdalla A. Elbashir, A new spectrophotometric method for the determination of cardiovascular drugs in dosage forms, American Academic \& Scholarly Research Journal 5(1) (2013), 106-121.

[37] Amit Asati, Anita Shinde, Suman Malik and K. C. Asati, Quantitative analysis method development and validation for irbesartan in bulk drug by ultraviolet spectroscopy, Journal of Advanced Pharmacy Education \& Research 4(1) (2014), 101-105.

[38] K. N. Tarkase, S. S. Suryawanshi and R. S. Joshi, Simultaneous derivative spectrophotometric determination and validation of losartan potassium in pharmaceutical dosage forms, International Journal of Pharmaceutical Sciences Review and Research 13(2) (2012), 31-34. 